\title{
The potent vasodilator ethyl nitrite is formed upon reaction of nitrite and ethanol under gastric conditions
}

\author{
Bruno Gago a,*, Thomas Nyström ${ }^{\mathrm{b}}$, Carlos Cavaleiro ${ }^{\mathrm{c}}$, Bárbara S. Rocha a ${ }^{\mathrm{a}}$, Rui M. Barbosa ${ }^{\mathrm{a}}$, \\ João Laranjinha ${ }^{\mathrm{a}}$, Jon O. Lundberg ${ }^{\mathrm{b}, *}$ \\ a Center for Neuroscience and Cell Biology and Faculty of Pharmacy, University of Coimbra, 3000 Coimbra, Portugal \\ ${ }^{\mathrm{b}}$ Department of Physiology and Pharmacology, Karolinska Institutet, S-171 77 Stockholm, Sweden \\ c Laboratory of Pharmacognosy, Faculty of Pharmacy/CEF, University of Coimbra, 3000 Coimbra, Portugal
}

\section{A R T I C L E I N F O}

\section{Article history:}

Received 24 January 2008

Revised 7 April 2008

Accepted 11 April 2008

Available online $\mathrm{xxxx}$

\section{Keywords:}

Ethyl nitrite

Nitrite

Ethanol

Red wine

Vasodilatation

Stomach

\begin{abstract}
A B S T R A C T
By acting as a bioreactor, affording chemical and mechanical conditions for the reaction between dietary components, the stomach may be a source of new bioactive molecules. Using gas chromatography-mass spectrometry we here demonstrate that, under acidic gastric conditions, ethyl nitrite is formed in $\mu \mathrm{M}$ concentrations from the reaction of red wine or distilled alcoholic drinks with physiological amounts of nitrite. Rat femoral artery rings and gastric fundus strips dose-dependently relaxed upon exposure to nitrite: ethanol mixtures. In contrast, when administered separately in the same dose ranges, nitrite evoked only minor vasorelaxation while ethanol actually caused a slight vasoconstriction. Mechanistically, the relaxation effect was assigned to generation of nitric oxide ( $\left.{ }^{\circ} \mathrm{NO}\right)$ as supported by direct demonstration of ${ }^{\circ} \mathrm{NO}$ release from ethyl nitrite and the absence of relaxation in the presence of the soluble guanylyl cyclase inhibitor, ODQ. In conclusion, these results suggest that ethanol in alcoholic drinks interacts with salivary-derived nitrite in the acidic stomach leading to the production of the potent smooth muscle relaxant ethyl nitrite. These findings reveal an alternative chemical reaction pathway for dietary nitrate and nitrite with possible impact on gastric physiology and pathophysiology.
\end{abstract}

(c) 2008 Elsevier Inc. All rights reserved.

\section{Introduction}

During the last decade, a lot of attention has been given to the biochemistry of nitrite in the human organism [1-5]. It is now clear that in the body, the nonenzymatic reduction of nitrite to "NO can occur under acidic conditions [6] such as in the stomach lumen [7-9], in acidified urine [10], on the skin surface [11,12] and in the oral cavity [13]. The equilibrium of nitrite with nitrous acid and other reactive nitrogen oxides at low $\mathrm{pH}$ is described by reactions 1 to 3 :

$$
\begin{aligned}
& \mathrm{NO}_{2}^{-}+\mathrm{H}^{+} \leftrightarrows \mathrm{HNO}_{2} \\
& 2 \mathrm{HNO}_{2} \leftrightarrows \mathrm{NO}+{ }^{\cdot} \mathrm{NO}_{2}+\mathrm{H}_{2} \mathrm{O} \\
& \cdot \mathrm{NO}+{ }^{\cdot} \mathrm{NO}_{2} \leftrightarrows \mathrm{N}_{2} \mathrm{O}_{3} .
\end{aligned}
$$

Abbreviations: •NO, Nitric oxide; KH, Krebs-Henseleit; ACh, Acetylcholine; DTPA, Diethylenetriaminepentaacetic acid; GSH, Glutathione; GSNO, S-Nitrosoglutathione; SNP, Sodium nitroprusside; ODQ [1,2,4] oxadiazolo[4,3,-a]quinoxalin-1-one; L-NAME, $N^{\omega}$-nitro-l-arginine methyl ester; GC-MS, Gas chromatography - Mass spectrometry; NOS, Nitric oxide synthase; sGC, Soluble guanylyl cyclase; RT, Retention time.

* Corresponding authors. Faculty of Pharmacy, University of Coimbra, Couraca Apostolos, 51, r/c, 3000 Coimbra, Portugal. Fax: +351 239852569.

E-mail address: bgago@cnc.uc.pt (B. Gago), jon.lundberg@ki.se (J.O. Lundberg).
Nitrite, the precursor of $\mathrm{HNO}_{2}$, derives from nutritional sources, from the reduction of dietary nitrate by oral commensal bacteria, and from oxidation of endogenous ${ }^{\circledR} \mathrm{NO}[2,5]$. The stomach is continuously exposed to nitrite through the swallowing of saliva, which is particularly rich in nitrite. The general view is that nitrite is only harmful to the GI tract because it can promote the generation of carcinogenic nitrosamines [14-18]. However, with the recent discovery of in vivo generation of $\mathrm{NO}$ from nitrite, a number of potentially beneficial effects are being revealed. These studies suggest a role for nitrite, ${ }^{\circ} \mathrm{NO}$ and its reaction products in host defense against gut pathogens [19], in regulation of gastric mucosal blood flow and mucous production $[20,21]$, and in protection against gastric ulcers [22].

Recently, we have shown that the consumption of red wine greatly increases the in vivo formation of "NO in the stomachs of healthy volunteers, via mechanisms that include the reduction of nitrite to ${ }^{\circ} \mathrm{NO}$ by wine polyphenols [23]. Ethanol represents another major constituent of wine that could potentially interact with nitrite under gastric conditions. From a chemical viewpoint, nitrite-derived reactive nitrogen species can react with aliphatic alcohols to yield alkyl nitrites by O-nitrosation of the corresponding alcohol [24]. Alkyl nitrites belong to the family of organic nitrites which are known for their potent vasodilatory activity. Considering that both, $\mathrm{HNO}_{2}[25]$ and $\mathrm{N}_{2} \mathrm{O}_{3}[26,27]$ may undergo such a reaction (reaction 4 and 5) they are 
likely candidates for a nitrosation reaction of ethanol in the acidic stomach generating ethyl nitrite in vivo.

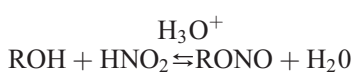

$\mathrm{ROH}+\mathrm{N}_{2} \mathrm{O}_{3} \leftrightharpoons \mathrm{RONO}+\mathrm{HNO}_{2}$

There have been a few earlier reports on the generation of ethyl nitrite in vivo. Macdonald and Jonsson detected ethyl nitrite in the breath of subjects who had been smoking and drinking concurrently, and the reaction of nitrogen oxides in the smoke with ethanol was suggested as its source [28]. More recently, Deng and colleagues showed that ethyl nitrite can be form in vivo after intraperitoneal administration of ethanol in rats and they proposed that its production proceeded via reaction of ethanol with peroxynitrite [29].

We aimed to study if ethyl nitrite is formed from alcoholic drinks and nitrite under simulated gastric conditions, and how such generation would be influenced by the concentration of nitrite and ethanol, $\mathrm{pH}$, and the type of alcoholic drink (red wine or brandy). Moreover, we attempted to confer physiological relevance of such interaction by studying the vasoactivity of a nitrite:ethanol mixture.

\section{Materials and methods}

\section{Chemicals and buffer solutions}

Ethanol p.a. (Ph.Eur) was obtained from Merck; ethyl nitrite (10\%$20 \%$ in ethanolic solution) was obtained from Aldrich and quantified as described below; [1,2,4] oxadiazolo[4,3,-a]quinoxalin-1-one (ODQ) was obtained from Tocris Cookson (Bristol, UK), acetylcholine (ACh), $N^{\omega}$-nitro-l-arginine methyl ester (L-NAME), phenylephrine, sodium nitrite, sodium nitroprusside (SNP), glutathione (GSH) and diethylenetriaminepentaacetic acid (DTPA) were obtained from Sigma Chemicals Co. Unless otherwise mentioned, pH 2.0 refers to simulated gastric juice without pepsin (USP 21). All solutions where prepared in ultrapure water. For the assays with the alcoholic drinks, single variety Touriga nacional red wine "Quinta de Cabriz" 2003 (14\% v/v), Dão, Portugal and brandy "Macieira" (40\% v/v), Portugal where used. All other reagents used were of analytical grade.

\section{Ethyl nitrite detection}

The detection of ethyl nitrite in the nitrite:ethanol mixtures was accomplished by solid-phase microextration and gas chromatography-mass spectrometry (GC-MS) techniques. Briefly, the reaction products of the sample (added with internal standard, 1,4-dioxane) were left to stabilize for $5 \mathrm{~min}$ in a sealed vial and then extracted from the headspace using a solid-phase microextration device (SPME fiber $50 / 30 \mu \mathrm{m}$ DVB/Carboxen/PDMS, Supelco, USA) at room temperature for $15 \mathrm{~min}$. Identification and quantification of ethyl nitrite in the extracts were made after direct thermal desorption from the SPME fiber inside the GC-MS injector. GC-MS system was composed by an Agilent Technologies 6890N gas chromatograph equipped with an SGE Carbowax column (polyethyleneglycol $25 \mathrm{~m} \times 220 \mu \mathrm{m}$, film thickness $0.25 \mu \mathrm{m}$ ) interfaced with a mass selective detector Agilent Technologies 5973N. GC-MS conditions were as follows: GC oven was started at $50^{\circ} \mathrm{C}$ for $1 \mathrm{~min}$, subsequently increased to $80^{\circ} \mathrm{C}$ at $10^{\circ} \mathrm{C}$ per minute and next to $160^{\circ} \mathrm{C}$ at $20^{\circ} \mathrm{C}$ per minute, and finally held at $160^{\circ} \mathrm{C}$ for $1 \mathrm{~min}$; Helium at $1.0 \mathrm{ml}^{\mathrm{min}}{ }^{-1}$ flow was used as carrier gas. Injector, in splitless mode, was kept at $250^{\circ} \mathrm{C}$. interface temperature: $250^{\circ} \mathrm{C}$; MS source temperature: $230^{\circ} \mathrm{C}$; MS quadrupole temperature: $150^{\circ} \mathrm{C}$; ionization energy: $70 \mathrm{eV}$; ionization current: $60 \mu \mathrm{A}$; scan range: $10-$ $350 \mathrm{amu}, 4.21$ scans. $\mathrm{s}^{-1}$.
The exact concentration of ethyl nitrite in the standard (Sigma) was determined by nuclear magnetic resonance in a Bruker AMX 300 spectrometer $(300.13 \mathrm{MHz}$, for $1 \mathrm{H})$ at $20^{\circ} \mathrm{C}$, with $\mathrm{CDCl}_{3}$ as solvent and TMS as internal reference. The valued achieved for ethyl nitrite concentration was $6 \%$ (weight/weight). This result agrees with previously published data [29]. Ethyl nitrite quantification was achieved by one-point calibration for each of the different experimental conditions.

\section{Ethyl nitrite production from a nitrite:ethanol mixture}

In order to characterise the production of ethyl nitrite from nitrite and ethanol in simulated gastric conditions, several reaction conditions were established, as described in figures legends. For the evaluation of ethyl nitrite production in red wine and brandy, both drinks were diluted in simulated gastric juice to reach a similar ethanol concentration and the final $\mathrm{pH}$ was set to 2.0. The buffer solutions at the defined $\mathrm{pH}$ and ethanol percentage were placed in $10 \mathrm{ml}$ headspace vials and sealed with aluminium caps with a silicon septum. Nitrite solution was added through the vial cap and followed immediately by the addition of $3 \mathrm{mM}$ 1,4-dioxane (internal standard). The final incubation volume was $3 \mathrm{ml}$. The mixture was let to equilibrate for $5 \mathrm{~min}$ and then followed by solid-phase microextraction for $15 \mathrm{~min}$ at room temperature of the gas-phase reaction products. The extracts were injected into the GC-MS for analysis.

\section{Spectrophotometric measurements}

Spectra of ethyl nitrite (standard) and S-Nitrosoglutathione (GSNO) were recorded in $50 \mathrm{mM}$ phosphate buffer saline at $\mathrm{pH} 7.4$ between 300 to $425 \mathrm{~nm}$. A Lambda 45 UV/VIS spectrophotometer (Perkin-Elmer Ltd., UK) was used at room temperature, under constant stirring and in the presence of $\mathrm{O}_{2}$.

\section{Nitric Oxide Measurements}

'NO in solution was measured electrochemically using the ISO-NO Mark II ${ }^{\circ} \mathrm{NO}$ meter and sensor (World Precision Instruments, LTD, Hertfordshire, UK). The sensor was calibrated in $\mathrm{KI}-\mathrm{H}_{2} \mathrm{SO}_{4}(0.1 \mathrm{M})$ with stock solutions of nitrite, according to the manufacturer protocol.

Gas phase "NO was measured by chemiluminescence (CLD 77, Ecophysics, Switzerland). The instrument's detection limit for "NO was $1 \mathrm{ppb}$. Calibration was performed with $\mathrm{NO}$ gas (10 ppm ${ }^{\circ} \mathrm{NO}$ in nitrogen; AGA AB, Lidingö, Sweden).

Nitric oxide production from ethyl nitrite standard and from nitrite: ethanol mixtures

To study the time course of ${ }^{\circ} \mathrm{NO}$ release from ethyl nitrite, $50 \mu \mathrm{M}$ ethyl nitrite (standard) was added to $50 \mathrm{mM}$ phosphate buffer saline at $\mathrm{pH} 7.4$ and the release of $\mathrm{NO}$ in solution was followed during 90 min. using the "NO sensor. The influence of GSH in the release profile of "NO from ethyl nitrite was assessed after addition of ethyl nitrite to 1 or $5 \mathrm{mM} \mathrm{GSH}$ in $50 \mathrm{mM}$ phosphate saline buffer at $\mathrm{pH}$ 7.4. In order to verify the influence of metal traces present in the buffer solutions, ${ }^{\circ} \mathrm{NO}$ release from $50 \mu \mathrm{M}$ ethyl nitrite was also performed in the presence of 10-100 $\mu \mathrm{M}$ DTPA. All assays were performed at room temperature, in the dark, under constant stirring and in the presence of $\mathrm{O}_{2}$.

The production of $\mathrm{NO}$ from the nitrite:ethanol mixture was studied at pH 2.0 by chemiluminescence. "For this $250 \mu \mathrm{M}$ nitrite was added to simulated gastric juice at $\mathrm{pH} 2.0$ in the presence and absence of $10 \%$ ethanol in a close reaction chamber from which a continuous flow of $\mathrm{N}_{2}$ removed ${ }^{\circ} \mathrm{NO}$ carrying it into the analyser. All the assays were made at $37^{\circ} \mathrm{C}$. The concentration of nitrite and the $\mathrm{pH}$ were chosen to resemble normal physiological conditions in the stomach. 


\section{Rat femoral artery rings}

Male Sprague-Dawley rats (weight 200-300 g) were given a pentobarbital overdose by intraperitoneal injection. The femoral arteries were carefully dissected free from surrounding tissue, removed and put in Krebs-Henseleit $(\mathrm{KH})$ solution $(118 \mathrm{mM} \mathrm{NaCl}$, $4.7 \mathrm{mM} \mathrm{KCl}, 1.2 \mathrm{mM} \mathrm{KH}_{2} \mathrm{PO}_{4}, 1.2 \mathrm{mM} \mathrm{MgSO}_{4}\left(\mathrm{H}_{2} \mathrm{O}\right), 25.2 \mathrm{mM} \mathrm{NaHCO}$, $2.5 \mathrm{mM} \mathrm{CaCl}_{2}$ and $11.1 \mathrm{mM}$ glucose). Circular segments (1 to $2 \mathrm{~mm}$ in length) of the femoral artery were mounted on two thin metal holders, one of which was connected to a force displacement transducer (model FT03, Grass Instrument, Quincy, MA) and the other to a movable device that allowed the application of a passive tension of 5 $\mathrm{mN}$. The tension was recorded on a Grass polygraph (model 7B). The mounted vascular segments were kept in organ baths containing $2 \mathrm{ml}$ $\mathrm{KH}$ solution at $37.5^{\circ} \mathrm{C}$ and were continuously bubbled with $6.5 \% \mathrm{CO}_{2}$ in $\mathrm{O}_{2}$ to maintain a $\mathrm{pH}$ of 7.4. After preparation, the vascular segments were allowed to equilibrate for $60 \mathrm{~min}$.

The contractile function of the vascular segments was tested by administration of phenylephrine ( $1 \mu \mathrm{M}$ final concentration) and with $\mathrm{K}^{+}$-rich $(127 \mathrm{mM}) \mathrm{KH}$ solution, prepared by replacing $\mathrm{NaCl}$ with equimolar amounts of $\mathrm{KCl}$. Endothelium-dependent and -independent relaxations were determined by administration of acethylcholine (Ach) and the $\mathrm{NO}$ donor sodium nitroprusside (SNP), respectively. ACh and SNP were added to the organ baths at cumulatively increasing concentrations ( $1 \mathrm{nM}$ to $10 \mu \mathrm{M}$ and $1 \mathrm{nM}$ to $1 \mu \mathrm{M}$, respectively) during a stable contractile tone induced by phenylephrine $(1 \mu \mathrm{M})$.

After testing the contractile and relaxatory function of the vascular segment phenylephrine was re-administered 15 min later and the vascular segment developed a stable contraction.

The nitrite:ethanol mixture ( $250 \mu \mathrm{M}$ sodium nitrite in $10 \%$ ethanol at $\mathrm{pH} 2.0$ followed by vortexing for $30 \mathrm{~s}$ ) was prepared and diluted in $\mathrm{KH}$ solution immediately before each administration to the organ bath. This stock solution contained $100 \mu \mathrm{M}$ ethyl nitrite as measured by GC-MS. All solutions were kept on ice to avoid evaporation of ethyl nitrite (boiling point $17^{\circ} \mathrm{C}$ ) and a new stock solution was prepared for each new administration. $10 \mu \mathrm{l}$ of the nitrite:ethanol mixture was added to the organ bath at cumulative increasing doses. The different nitrite:ethanol mixtures gave final concentrations of 50,100, 125, 165, 250 and $510 \mathrm{nM}$ ethyl nitrite in the organ bath (Fig. 6A). In separate experiments, and in order to exclude the influence of "NO derived from nitric oxide synthase (NOS), the nitrite:ethanol mixture was also administered to pre-contracted vascular segments which had been incubated with the "NO synthase inhibitor L-NAME at a final concentration of $1 \mathrm{mM}$. Also, to demonstrate the "NO-dependent relaxatory effect of ethyl nitrite, the nitrite:ethanol mixture was administered to pre-contracted vascular segments which had been incubated with the soluble guanylyl cyclase inhibitor ODQ [30] $1 \mu \mathrm{M}$. To reveal any effect of the individual compounds contained in the nitrite:ethanol mixture, control experiments with nitrite or ethanol alone were run by adding the total cumulative doses $3 \mu \mathrm{M}$ (nitrite) and $0.12 \%$ (ethanol) prepared at $\mathrm{pH} 2.0$.

\section{Rat fundus stomach strips}

Wistar rats (250-350 g) were killed by cervical displacement according to approved guidelines. The abdomen was opened and the stomach removed. The fundus was dissected and washed in fresh $\mathrm{KH}$. Following this, longitudinal strips $(1.5 \times 15 \mathrm{~mm})$ were carefully prepared and mounted vertically in the organ bath $(10 \mathrm{ml}$ capacity) containing $\mathrm{KH}$ bubbled with $6.5 \% \mathrm{CO}_{2}$ in $\mathrm{O}_{2}$. Tissues were mounted under an initial resting tension of $2 \mathrm{~g}$ and left to equilibrate for a period of $120 \mathrm{~min}$. Tension changes were recorded using a MLT050/D isometric force transducers couple to a bridge amplifier ML224 and PowerLab 4/30 data acquisition system (AD Instruments, Australia).
Rat fundus stomach strips were pre-contracted with $5 \mu \mathrm{M}$ carbachol and let to equilibrate until a stable contraction was reached ( $\pm 5 \mathrm{~min}$ ). The nitrite:ethanol mixtures of 250 and $1000 \mu \mathrm{M}$ sodium nitrite in $10 \%$ ethanol at $\mathrm{pH} 2.0$ were prepared immediately before administration to the organ bath. These solutions contained 100 and $500 \mu \mathrm{M}$ ethyl nitrite respectively as measured by GC-MS. The nitrite: ethanol mixtures gave final concentrations of 0.5 and $2.5 \mu \mathrm{M}$ ethyl nitrite in the organ bath. Control experiments with nitrite or ethanol alone at $\mathrm{pH} 2.0$ were run with final concentrations in the organ bath of 1.25 and $5 \mu \mathrm{M}$ (nitrite) and 0.05\% (ethanol).

\section{Statistical analysis and data presentation}

Statistical analysis was performed by one-way Anova variance followed by Dunnett's test. In the case of two-sample comparisons, an unpaired $t$ test was used. Differences were considered statistically significant at $p<0.05$.

Contractions of the artery segments and the stomach strips are expressed as the percentage of phenylephrine or carbachol-induced contractions. The pre-contracted level was set to $0 \%$, and the baseline level, corresponding to maximal relaxation, of $100 \%$. All values were expressed as mean \pm S.E.M.

\section{Results}

\section{Ethyl nitrite detection and quantification}

The electron impact ionization mass spectrum for ethyl nitrite in the mixture of $250 \mu \mathrm{M}$ nitrite in $10 \%$ ethanol at $\mathrm{pH} 2.0$ (Fig. 1) is consistent with those reported in the literature [29,31]. Mass spectrum was acquired at retention time (RT) of $1.15 \mathrm{~min}$ and it is also consistent with that obtained from ethyl nitrite standard at $\mathrm{pH} 2.0$ (data not shown), clearly identifying the production of ethyl nitrite in the nitrite:ethanol mixture.

Quantification of ethyl nitrite in a range of concentrations from $1 \mu \mathrm{M}$ to $600 \mu \mathrm{M}$ can be achieved from extracted ion chromatograms, considering the ratios of the peak areas at RT 1.15 and at RT 3.30 when monitoring ion $\mathrm{CH}_{2} \mathrm{ONO}^{+}(\mathrm{m} / \mathrm{z}=60)$ characteristic for ethyl nitrite and 1,4 -dioxane molecular ion $(\mathrm{m} / \mathrm{z}=88)$ in samples and standard solutions.

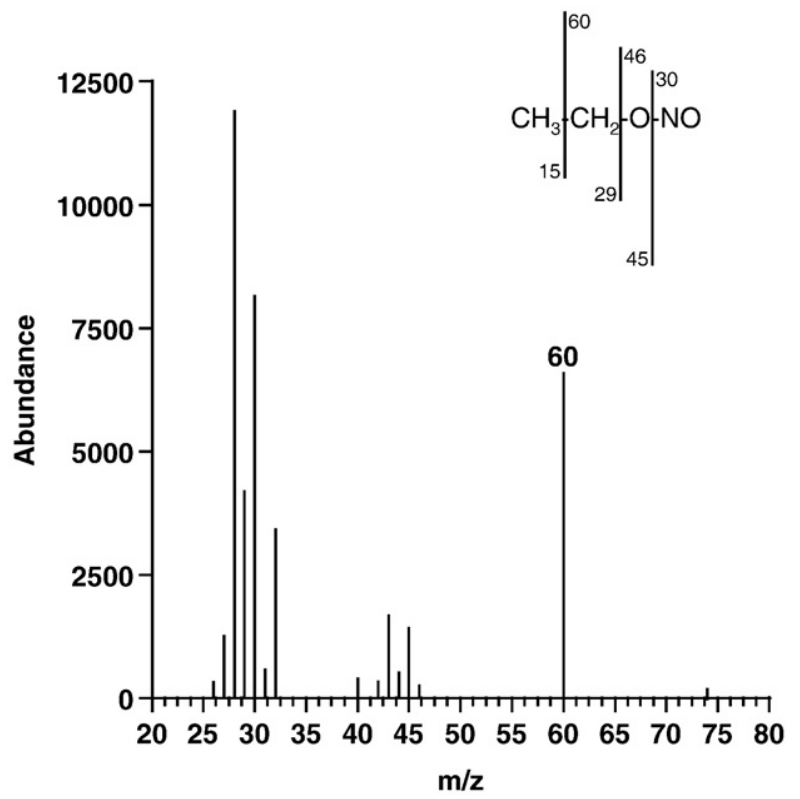

Fig. 1. GC-MS identification of ethyl nitrite. Electron ionization mass spectrum of the nitrite:ethanol mixture at RT $1.15 \mathrm{~min}$. Mixture of $250 \mu \mathrm{M}$ nitrite in $10 \%$ ethanol at pH 2.0. 
A

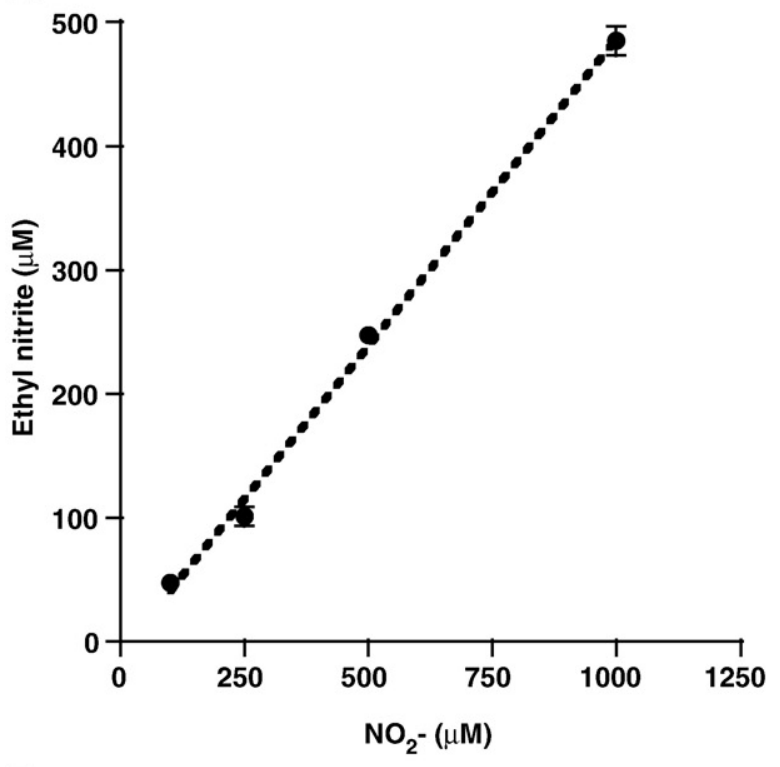

B

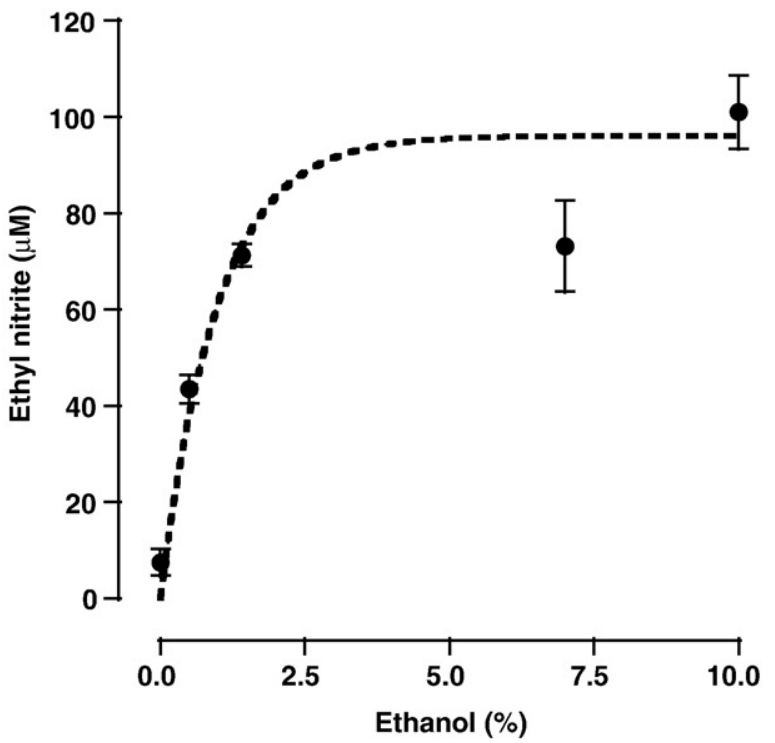

C

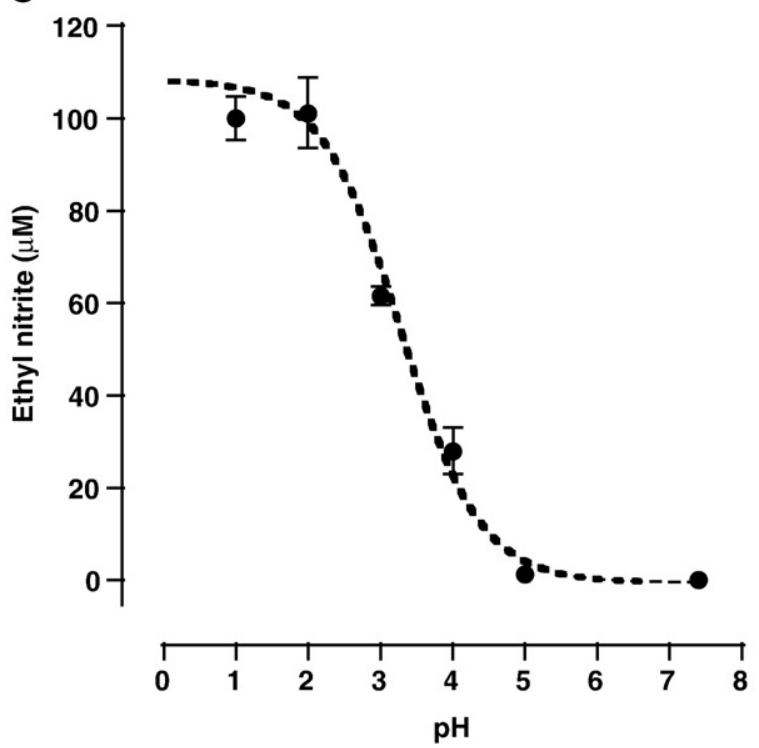

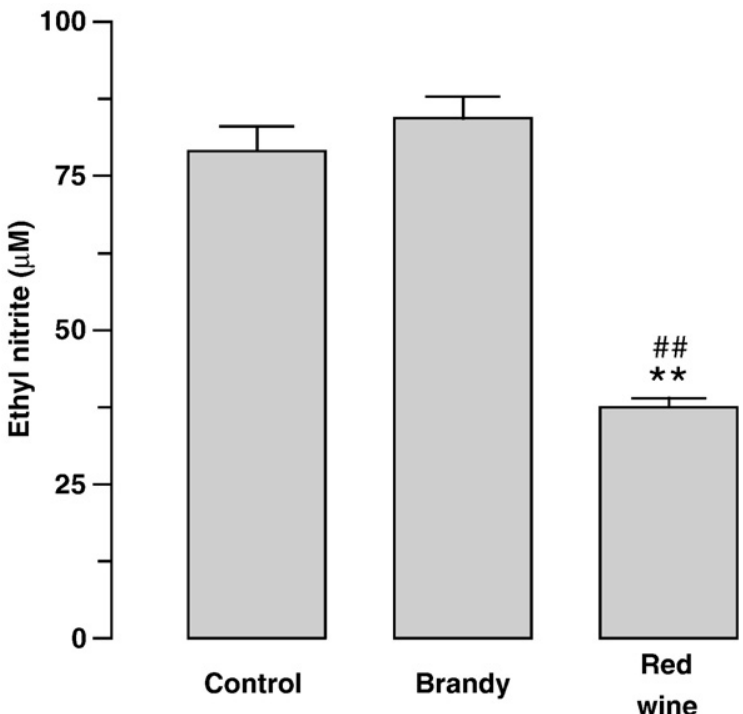

Fig. 3. Ethyl nitrite production from $250 \mu \mathrm{M}$ nitrite in alcoholic drinks at $\mathrm{pH} 2.0$. Wine and brandy were diluted to reach the concentration of $7 \%$ ethanol and the $\mathrm{pH}$ fixed to 2.0. Values are mean \pm S.E.M. ${ }^{* *} p<0.01$ relative to control, ${ }^{\# \#} p<0.01$ relative to brandy.

\section{Ethyl nitrite production under simulated gastric conditions}

The production of ethyl nitrite was studied as a function of $\mathrm{pH}$ as well as of nitrite and ethanol concentration (Fig. 2). Concentrations in a range compatible with those found in vivo following food intake were used, comprising 100 to $1000 \mu \mathrm{M}$ for nitrite, $0.015(2.5 \mathrm{mM})$ to $10 \%(1.7 \mathrm{M})$ for ethanol, and a $\mathrm{pH}$ range between 1.0 and 7.4 . The mixture of $250 \mu \mathrm{M}$ nitrite with $10 \%$ ethanol at $\mathrm{pH} 2.0$ was chosen as a representative dietary condition. For $10 \%$ ethanol at $\mathrm{pH} 2.0$ the production of ethyl nitrite is a linear function of nitrite concentration (Fig. 2A). For $250 \mu \mathrm{M}$ nitrite the ethyl nitrite production was $101.0 \pm$ $33.3 \mu \mathrm{M}$. When varying the concentration of ethanol for a constant concentration of $250 \mu \mathrm{M}$ nitrite, the formation of ethyl nitrite increases up to $1.4 \%$ ethanol (Fig. $2 \mathrm{~B}$ ) but with higher ethanol concentrations no further increase was found, suggesting a saturation beyond this concentration of ethanol.

The $\mathrm{pH}$ critically affected the formation of ethyl nitrite. As shown in Fig. 2C, the addition of $250 \mu \mathrm{M}$ nitrite to $10 \%$ ethanol generated around $100 \mu \mathrm{M}$ ethyl nitrite in the $\mathrm{pH}$ range between 1.0 and 2.0 (physiological $\mathrm{pH}$ of the fasting stomach), dropping sharply at higher $\mathrm{pH}$ values. At $\mathrm{pH} 3.3$ (curve extrapolation) the $\mathrm{pK}_{a}$ of $\mathrm{HNO}_{2}$, ethyl nitrite formation was about $50 \%$ of maximum. At pH 5.0, $1.2 \pm 0.8 \mu \mathrm{M}$ ethyl nitrite was produced, while at $\mathrm{pH} 7.4$ the levels were below the detection limit.

Two different alcoholic drinks were used as a source of ethanol, red wine $(14 \% \mathrm{v} / \mathrm{v})$ and brandy $(40 \% \mathrm{v} / \mathrm{v})$. These beverages represent two different sources of ethanol, fermentation for red wine and distillation for brandy. In addition they differ in polyphenols content (compounds that may potentially interfere in ethyl nitrite production), which is higher in red wine [32-34]. Finally, a solution of ethanol (p.a.) was used as control. Fig. 3 shows the formation of ethyl nitrite at $\mathrm{pH} 2.0$ when $250 \mu \mathrm{M}$ nitrite reacted with diluted red wine or brandy (final ethanol concentration of 7\%). Under these conditions, the production of ethyl nitrite promoted by red wine, brandy and ethanol solution (control) was $38 \pm 1.4,84 \pm 3.4$ and $79 \pm 4.0 \mu \mathrm{M}$ respectively. There was a significant difference $(p<0.01)$ between red wine and control but not between control and brandy $(p>0.05)$.

Fig. 2. Ethyl nitrite production from nitrite:ethanol mixture. A) 100, 250, 500 and $1000 \mu \mathrm{M}$ nitrite in $10 \%$ ethanol at $\mathrm{pH} 2.0$; B) $250 \mu \mathrm{M}$ nitrite in $0.015,0.5,1.4,7$ and $10 \%$ ethanol at $\mathrm{pH} 2.0$; C) $250 \mu \mathrm{M}$ nitrite in $10 \%$ ethanol at $\mathrm{pH} 1.0,2.0,3.0,4.0,5.0$ and 7.4 . Values are mean \pm S.E.M. 
Nitric oxide release from ethyl nitrite standards and from nitrite:ethanol mixtures: Effect of gluthathione

Fig. 4A shows a representative tracing of ${ }^{\circ} \mathrm{NO}$ release from $50 \mu \mathrm{M}$ ethyl nitrite standard in $50 \mathrm{mM}$ phosphate buffer saline at $\mathrm{pH} 7.4$ alone (Fig. 4A. line a) or in the presence of $5 \mathrm{mM} \mathrm{GSH}$ (Fig. 4A, line b). The maximal releases of ${ }^{\circ} \mathrm{NO}$ and the $\mathrm{t}_{80}$ are presented in Table 1 . The results show that the presence of GSH in the medium decreases the maximal release of ${ }^{\circ} \mathrm{NO}$ from ethyl nitrite (Fig. 4A, line a versus line $b$ ). In separate experiments $10-100 \mu \mathrm{M}$ DTPA was added to the buffer solution to study the influence of metal traces on "NO release from ethyl nitrite ( $50 \mu \mathrm{M}$ ethyl nitrite at $\mathrm{pH}$ 7.4). No changes were observed in ${ }^{N O}$ release in the presence of DTPA (data not shown). At pH 7.4, ethyl nitrite concentration decreases with time, as followed spectrophotometrically at $280 \mathrm{~nm}$ (not shown). In the presence of

\section{A}

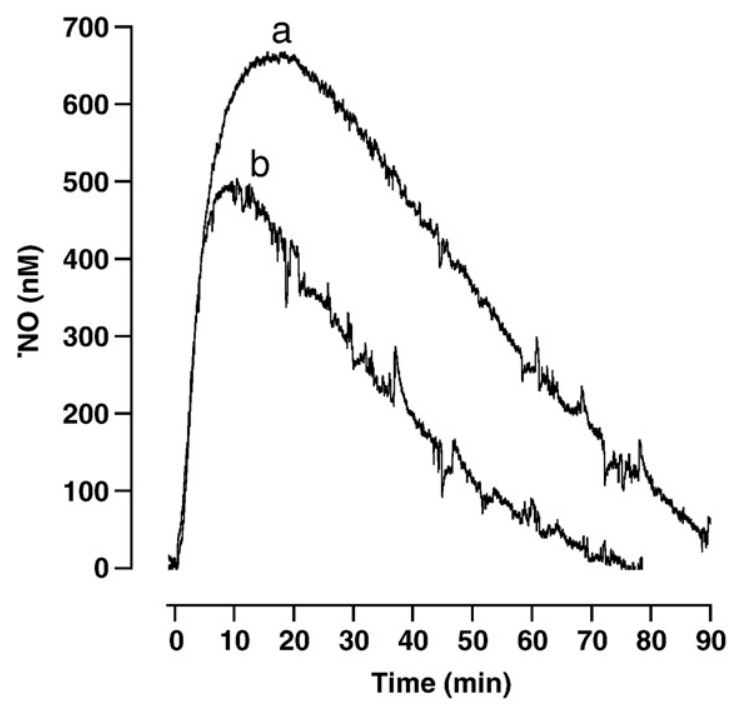

B

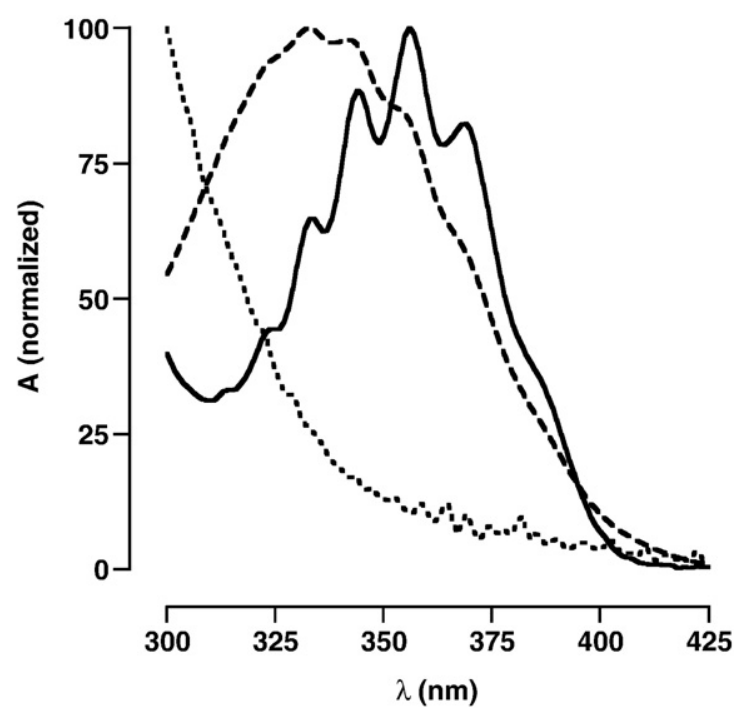

Fig. 4. "NO release from ethyl nitrite at $\mathrm{pH}$ 7.4. A) Representative time course of ${ }^{\circ} \mathrm{NO}$ release from, $50 \mu \mathrm{M}$ ethyl nitrite in the absence (line a) or presence (line b) of $5 \mathrm{mM}$ GSH. "NO detection was made electrochemically, in the dark, at room temperature and under constant stirring; B) GSNO production from GSH and ethyl nitrite at $\mathrm{pH}$ 7.4. Spectrum of $5 \mathrm{mM} \mathrm{GSH}(\cdots), 1 \mathrm{mM}$ ethyl nitrite (-) and from the mixture of $5 \mathrm{mM} \mathrm{GSH}$ and $1 \mathrm{mM}$ ethyl nitrite (---). Spectra were taken immediately after the addition of ethyl nitrite, at room temperature, under constant stirring. All assays were made in phosphate buffer saline at $\mathrm{pH} 7.4$ prepared with ultra pure water.
Table 1

NO release from $50 \mu \mathrm{M}$ ethyl nitrite at $\mathrm{pH} 7.4$ in the presence of GSH

\begin{tabular}{cll}
\hline & NO Peak $(\mathrm{nM})$ & $\mathrm{t}_{80}(\mathrm{~min})$ \\
\hline Ethyl nitrite $(\mathrm{n}=8)$ & $970 \pm 36$ & $8.7 \pm 0.9$ \\
$+1 \mathrm{mM} \mathrm{GSH}(\mathrm{n}=3)$ & $801 \pm 54^{*}$ & $7.8 \pm 0.1$ \\
$+5 \mathrm{mM} \mathrm{GSH}(\mathrm{n}=3)$ & $610 \pm 31^{* *}$ & $3.9 \pm 0.2^{* *}$ \\
\hline
\end{tabular}

Values are mean \pm S.E.M.; $* p<0.05, * * p<0.01$, compared to ethyl nitrite alone.

$5 \mathrm{mM} \mathrm{GSH}$ at $\mathrm{pH} 7.4$, the addition of $1 \mathrm{mM}$ ethyl nitrite promotes the formation of GSNO as detected by the typical absorption maximum of RSNO at $336 \mathrm{~nm}$ (Fig. 4B, dashed line). Fig. 4B, dot line and solid line represent the spectra of GSH and ethyl nitrite, respectively.

Fig. 5 shows the release of "NO from the nitrite:ethanol mixture and from nitrite alone. As expected, at this acidic $\mathrm{pH}$, nitrite spontaneously yielded ${ }^{\circ} \mathrm{NO}$. The presence of ethanol however led to an almost $80 \%$ decrease in ${ }^{\circ} \mathrm{NO}$ release most likely due to the formation of ethyl nitrite. Such ${ }^{\circ} \mathrm{NO}$ scavenging effect of ethanol has been described before [35].

Rat femoral artery rings and gastric fundus strips: responses to nitrite: ethanol

A dose-dependent vascular relaxation was obtained when the nitrite:ethanol mixtures were added to the femoral artery rings (Fig. 6). For the initial dose of $50 \mathrm{nM}$ ethyl nitrite $10 \pm 3 \%$ relaxation was observed. $50 \%$ of relaxatory effect $\left(\mathrm{EC}_{50}\right)$ was accomplished with the cumulative dose of $198 \pm 11 \mathrm{nM}$ ethyl nitrite and a complete relaxation was achieved for the cumulative dose of $1.2 \mu \mathrm{M}$ ethyl nitrite (Fig. 6B, close circles). The dose-response curve was not significantly changed in the presence of $1 \mathrm{mM}$ L-NAME (Fig. 6B, open circles). In contrast in the presence of $1 \mu \mathrm{M}$ ODQ the dose-response curve for ethyl nitrite was strongly rightward shifted (Fig. 6B, open squares). A small but significant relaxation $(10 \pm 3 \%, p<0.05)$ was produced by nitrite alone $(3 \mu \mathrm{M})$ while ethanol $(20.6 \mathrm{mM}-0.12 \%)$ alone evoked a significant contraction ( $12 \pm 4 \%, p<0.05$, Fig. $6 \mathrm{C})$.

The pre-contracted gastric fundus strips relaxed dose-dependently in response to nitrite:ethanol mixtures (Table 2). In contrast, control

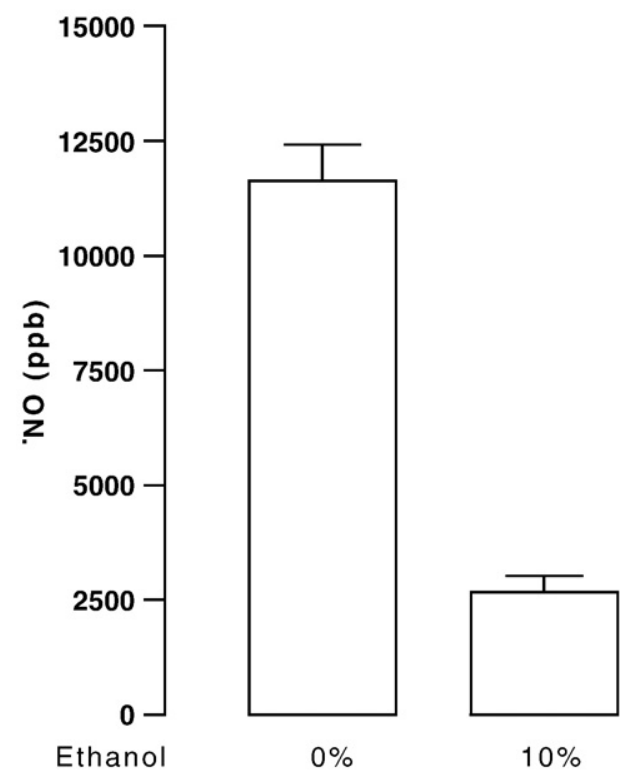

Fig. 5. ${ }^{\mathrm{NO}}$ release after addition of $250 \mu \mathrm{M}$ nitrite to either $0 \%$ or $10 \%$ ethanol at $\mathrm{pH} 2.0$. Values are mean \pm S.E.M. "NO detection was made by chemiluminescence in the headspace of the reaction chamber. Acidified nitrite yields ${ }^{*} N O$ via disproportionation. With ethanol less free ${ }^{*} \mathrm{NO}$ is detected due to rapid formation of ethyl nitrite. 


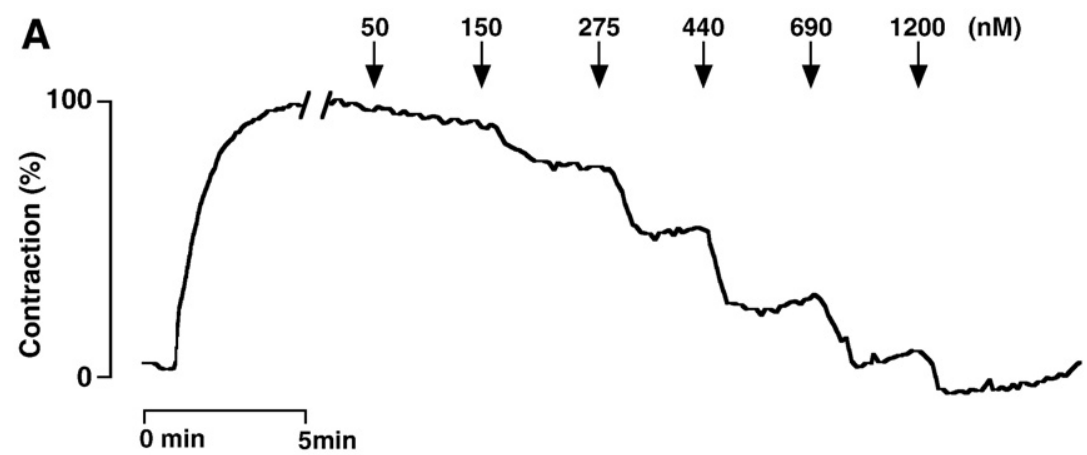

B

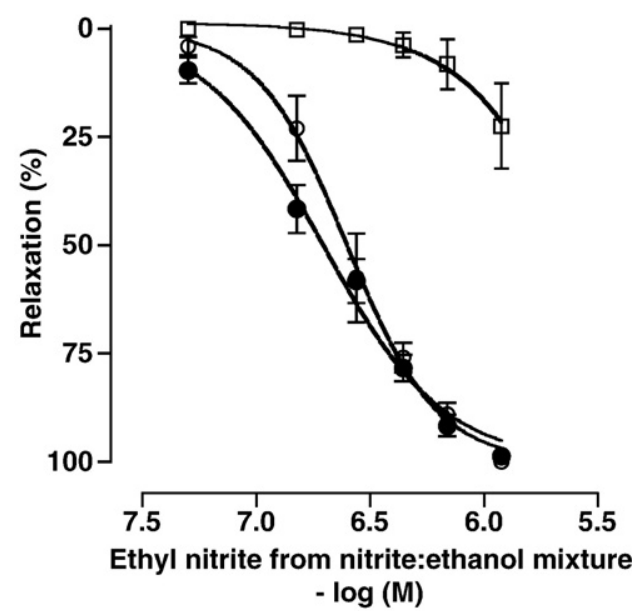

C

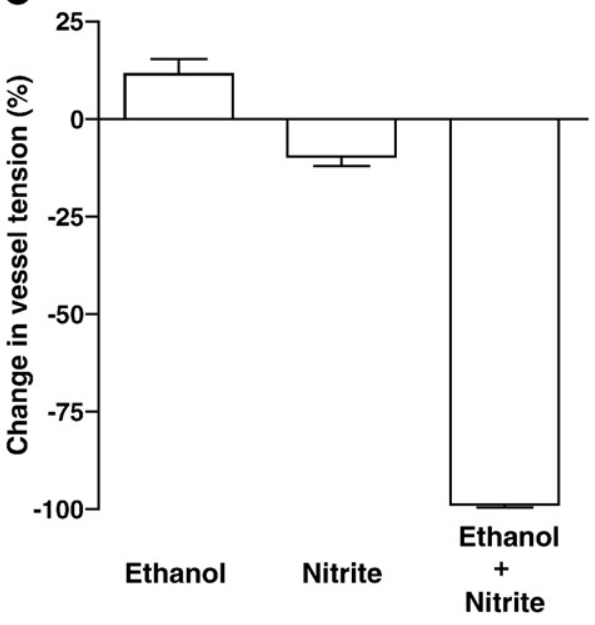

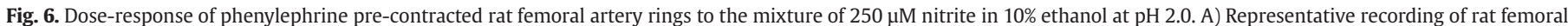

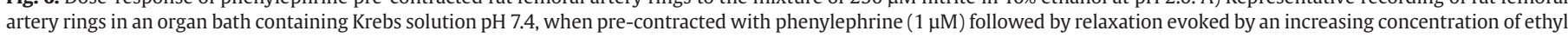

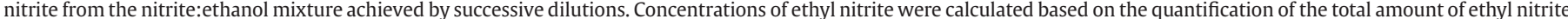

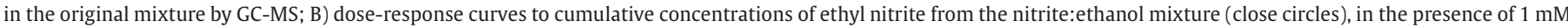

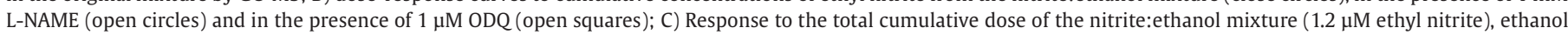
alone $(0.12 \%)$ and nitrite alone $(3 \mu \mathrm{M})$ at $\mathrm{pH} 2.0$.

strips exposed to the same amounts of nitrite or ethanol alone, showed no significant change in tension (data not shown).

\section{Discussion}

Nitrite is now emerging as an important alternative substrate for ${ }^{\circ} \mathrm{NO}$ generation in processes that are independent on ${ }^{\circ} \mathrm{NO}$ synthases. [1-6]. "NO formation from nitrite proceeds via enzymatic as well as non-enzymatic pathways. Nonenzymatic acid-catalyzed reduction of nitrite to $\mathrm{NO}$ is the predominate pathway in the stomach $[6,8,9]$.

In a previous study we have shown that consumption of red wine increases intragastric ${ }^{\circ} \mathrm{NO}$ formation following the intake of nitrate and suggested a role for wine polyphenols as catalysts of nitrite reduction to ${ }^{*} \mathrm{NO}$ [23]. Considering the well-known reaction of aliphatic alcohols with $\mathrm{HNO}_{2}$ to yield alkyl nitrites [25] by O-nitrosation [24] it became pertinent to asses whether the ethanol component of alcoholic drinks, would react with nitrite, and if the reaction product would be bioactive. Clearly, it is demonstrated here that the ethanol content of red wine and other alcoholic drinks, at dilutions found in vivo, reacts with physiological amounts of nitrite under gatric conditions to yield ethyl nitrite (Fig. 3) a compound endowed with vasoactive properties (Fig. 6) via "NO release (Figs. 4 and 5).

Chemically the formation of ethyl nitrite may encompass reaction 4 and 5 , in which alcohols react with $\mathrm{HNO}_{2}[36,37]$ and $\mathrm{N}_{2} \mathrm{O}_{3}$
[26,27,38] to generate alkyl nitrites. Given that nitrite is continually produced in human saliva by oral commensal bacteria $[13,39,40]$, $\mathrm{HNO}_{2}$ will be present in the gastric juice as long as a low $\mathrm{pH}$ is maintained. Via its reduction, $\mathrm{HNO}_{2}$ produces high levels of ${ }^{\circ} \mathrm{NO}$ in the stomach lumen $[8,9,20,23]$ which in turn is in equilibrium with $\mathrm{N}_{2} \mathrm{O}_{3}$ (reaction 3). In this scenario when ethanol reaches the gastric compartment it is likely to react with both, $\mathrm{HNO}_{2}$ and $\mathrm{N}_{2} \mathrm{O}_{3}$, and Onitrosation reactions are prone to happen. These reactions will depend not only on the rate constants for the individual reactions that govern the complex equilibrium between nitrogen oxides, but also on several

Table 2

Relaxation of carbachol pre-contracted rat fundus stomach strips in response to a nitrite:ethanol mixture

\begin{tabular}{ll}
\hline Nitrite:ethanol mixture ( $\mu \mathrm{M}$ ethyl nitrite) & $\%$ of relaxation \\
\hline 0.5 & $17 \pm 4$ \\
2.5 & $57 \pm 5^{* * *}$
\end{tabular}

$50 \mu \mathrm{l}$ of nitrite:ethanol mixtures ( 250 or $1000 \mu \mathrm{M}$ nitrite in $10 \%$ ethanol at $\mathrm{pH} 2.0$ ) were added to the organ bath $(10 \mathrm{ml})$ and the relaxatory response was determined. Controls with the same amounts of nitrite or ethanol alone evoked no significant changes in tension. Ethyl nitrite values represent the final calculated concentrations in the organ bath as detected by GC-MS in the original nitrite:ethanol mixtures. Values are mean \pm S.E.M. $(\mathrm{n}=16) ; * * * \mathrm{p}<0.0001$ (unpaired t test). 


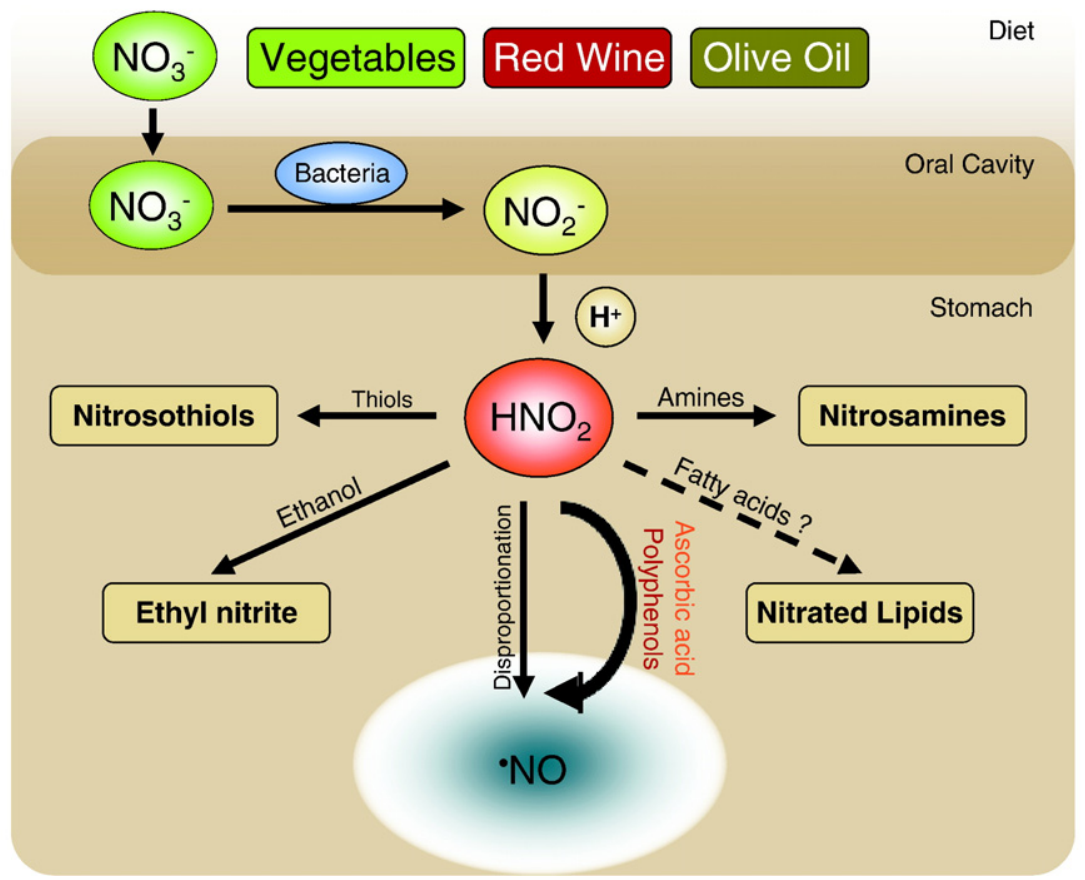

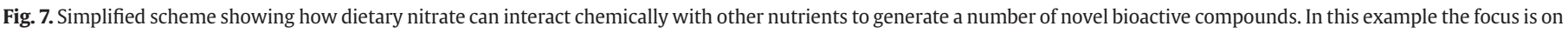

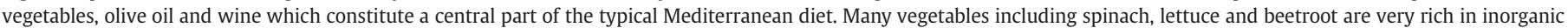

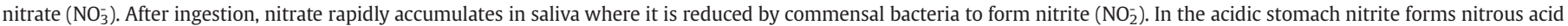

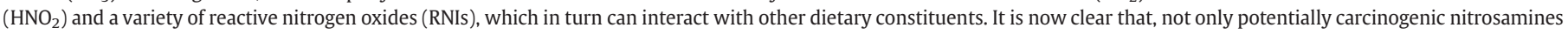

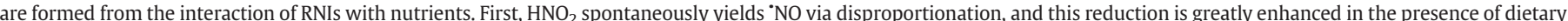

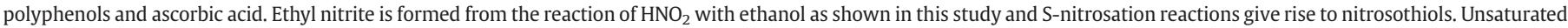

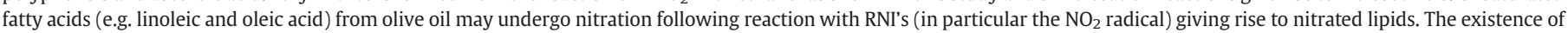

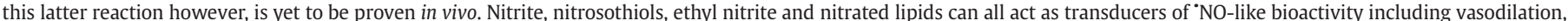

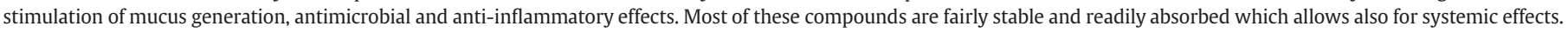

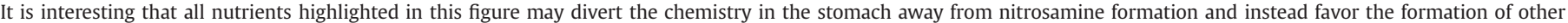

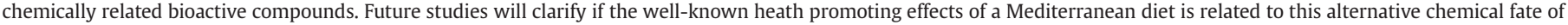
dietary nitrate.

variables and conditions present in the stomach lumen. In particular the following may be considered:

(1) The amount of nitrite in saliva will directly influence the levels of $\mathrm{N}_{2} \mathrm{O}_{3}, \mathrm{HNO}_{2}$ and ${ }^{\circ} \mathrm{NO}$ in the stomach [20] and thereby also the levels of ethyl nitrite (Fig. 2A); (2) ethanol acts as subtract for nitrosation and small changes in its concentration will influence the production of ethyl nitrite. In a normal situation after ethanol consumption, ethanol will be in large excess compared to $\mathrm{HNO}_{2}$. As shown in Fig. 2B, ethanol $(0.015 \%)$ and nitrite $(250 \mu \mathrm{M})$ yields low amounts of ethyl nitrite but already at $1.4 \%$ the levels had reached a plateau and were not statistical different from the ones achieved for $10 \%$ ethanol, demonstrating that nitrite is likely the limiting factor; (3) pH influences the equilibrium between all the nitrosative species. An increase in $\mathrm{pH}$ from 2.0 (fasting) to 5.0 (post-prandial) results in major changes in the equilibrium between the different nitrogen oxides with reduced $\mathrm{HNO}_{2}$ and $\mathrm{N}_{2} \mathrm{O}_{3}$ concentrations. For $\mathrm{pH}$ values lower than 3.0, ethyl nitrite production was independent of $\mathrm{pH}$, but when $\mathrm{pH}$ increases above the $\mathrm{pK}_{a}$ of $\mathrm{HNO}_{2}$ $(\sim 3.3)$, a rapid decrease was observed (Fig. 2C). This demonstrates the crucial importance of $\mathrm{HNO}_{2}$ for ethanol O-nitrosation in the stomach; (4) the content of $\mathrm{HNO}_{2}$-reducing agents like polyphenols and ascorbic acid, affects reaction 2 , shifting it to the right with an increase in "NO production [23,41-43]. Ethyl nitrite production was more than 2 times lower for red wine compared with brandy or the control ethanol solution. In contrast to brandy [34], red wine has a high polyphenolic content $[32,33]$. These polyphenols $(\mathrm{Ph}-\mathrm{OH})$ greatly accelerate ${ }^{\circ} \mathrm{NO}$ formation from $\mathrm{HNO}_{2}$ as shown in recent studies [23,41]:

$\mathrm{Ph}-\mathrm{OH}+\mathrm{HNO}_{2} \rightarrow \mathrm{Ph}-\mathrm{O}^{\bullet}+{ }^{\bullet} \mathrm{NO}+\mathrm{H}_{2} \mathrm{O}$.

Taking into consideration reactions 4 and 6 , the red wine phenols will compete for $\mathrm{HNO}_{2}$ thereby diminishing the nitrosation reaction of ethanol.
In the bioassay studies with rat femoral artery rings, the nitrite: ethanol mixture produced a dose-dependent relaxation with an $\mathrm{EC}_{50}$ around $200 \mathrm{nM}$ (Fig. 6). In blood the half-lives of alkyl nitrites are in the range of seconds (isobutyl nitrite around $1.4 \mathrm{~min}$ ) [44], and they can decompose by nonenzymatic hydrolysis as well as by enzymatic cleavage. In the case of ethyl nitrite it is known that it spontaneously releases low fluxes of $\mathrm{NO}$ in aqueous solution [45] by homolytic cleavage of the $\mathrm{O}-\mathrm{NO}$ bond [46].The inhibition of vascular relaxation in the presence of ODQ and the inability of L-NAME to block the vasodilatory effect, strongly suggest that the relaxation was caused by NO from ethyl nitrite. One might argue that ethanol and nitrite produced these effects independently of ethyl nitrite formation, since vasoactivity has been described for both these compounds $[47,48]$. However, when applied in high concentrations separately, ethanol and nitrite were devoid of significant vasodilatory activity. In fact, with ethanol we even noted a minor vasoconstriction (Fig. 6C) which is in accordance with recent studies [49]. The small vascular relaxation observed with nitrite alone when prepared at pH 2.0 (Fig. 6C) is likely a result of free dissolved "NO being generated by acidic disproportionation (this reaction stops abruptly however, once the solution is mixed with the physiological buffer in the organ baths). With the combined nitrite: ethanol mixture profound vasorelaxation occurred despite less free "NO being generated in the solution (Fig. 5), supporting ethyl nitrite as being the active component. Likely, this ethyl nitrite readily diffuses into the smooth muscle where it effectively releases ${ }^{\circ} \mathrm{NO}$ in close vicinity of the guanylyl cyclase.

On the other hand, since ethyl nitrite is endowed with nitrosative properties, transnitrosation reactions are prone to occur in the presence of subtracts like alcohols, thiols and amines. As shown in Fig. 4 and in Table 1, there is a decrease in maximal release of ${ }^{\circ} \mathrm{NO}$ from ethyl 
nitrite in the presence of GSH; an observation in accordance with the transnitrosation of the $\mathrm{NO}$ moiety from ethyl nitrite (Fig. 4B, solid line) to GSH (Fig. 4B, dotted line a), with the final formation of GSNO (Fig. 4B, dashed line). GSNO is a more stable product and ${ }^{\circ} \mathrm{NO}$ release will be less obvious.

The rapid transnitrosation reaction between ethyl nitrite and GSH will transfer the "NO-like" biological activity of ethyl nitrite to GSNO.

From this study it is also clear that the yield of ethyl nitrite from nitrite:ethanol mixture is rapid and remarkably large under acidic conditions. In fact in the vitro experiments almost $50 \%$ of added nitrite instantly formed ethyl nitrite (Fig. 2A). In contrast, under the same conditions but without ethanol the formation of ${ }^{\circ} \mathrm{NO}$ from nitrite via acidic disproportionation is much slower.

The pharmacological effects of alkyl nitrites have been known for almost a century and ethyl nitrite is being tested in clinical studies as a hemodynamic regulator for treatment of hypertension in the newborn [50] and in animals during laparoscopic procedures [51], and in reversing surgical vasospasm [52]. In the stomach ethyl nitrite will easily reach $\mu \mathrm{M}$ concentration and it is very likely that it will have biological effects. For nitrite such effects have already been shown and they include mucosal vasodilatation, increased mucus generation, destruction of pathogens and protection against gastric ulcer [19,20,22]. While NO formation from nitrite and ethyl nitrite can clearly be beneficial in gastroprotection, detrimental effects have also been suggested including formation of carcinogenic nitrosamines from nitrite/"NO and its reaction products [18]. It is not known how ethyl nitrite will affect these potentially carcinogenic pathways. It will be interesting to study if ethyl nitrite can survive passage to deeper mucosal structures and cause relaxations of the underlying smooth muscle layer. This effect is in fact suggested by the relaxatory effect of the nitrite:ethanol mixture seen in the experiments with rat stomach strips (Table 2) [53]. Such effects if they occur also in vivo, could contribute to gastric adaptive responses as well as the cardia relaxation and concomitant gastro-esophageal reflux commonly seen after alcohol ingestion [54-56]. Finally, an intriguing but yet unproven possibility exists that some ethyl nitrite is absorbed intact in the GI tract, escapes liver metabolism to reach the systemic circulation. In this context it is tempting to speculate that some of the described acute effects of ethanol on the cardiovascular system (such as reduction in blood pressure and increases in forearm blood flow) $[48,57,58]$, involve $\mathrm{NO}$ release from circulating ethyl nitrite.

This study and other recent reports $[23,59]$ highlight the stomach as a bioreactor were bioactive molecules are produced from common dietary components. For dietary nitrate the focus over the past 50 years has been entirely on the formation of potentially carcinogenic nitrosamines via nitrite-mediated $\mathrm{N}$-nitrosation $[14,18]$. It is now becoming clear however, that a variety of other bioactive compounds are formed from nitrite under acidic gastric conditions (Fig. 7). These include ${ }^{*} \mathrm{NO}, \mathrm{S}$ nitrosothiols [20], as well as O-nitrosation products such as the ethyl nitrite described here. In addition, nitration reactions will likely occur including the formation of nitroalkenes from dietary unsaturated fatty acids. The latter is an interesting possibility, as nitroalkenes have powerful anti-inflammatory activity in vitro [60]. In general, it is becoming clear that dietary nitrate and its reaction products are not necessarily a threat to human health. In fact, numerous recent studies now imply beneficial effects of nitrate in the gastrointestinal tract and the cardiovascular system [5]. The nutritional implications of this are potentially intriguing. As an example, the typical Mediterranean diet with a high intake of vegetables, fruits, olive oil and wine, provides a rich supply of nitrate/nitrite, polyphenols, unsaturated fatty acids and ethanol. It remains to be studied if the well-known health promoting effects of this diet in any way is related to the chemical interactions between these dietary components.

We conclude that the potent vasodilator ethyl nitrite is generated under gastric conditions from physiological amounts of nitrite and ethanol in red wine or brandy. The physiological and pathtophysiological role of gastric ethyl nitrite formation remains to be elucidated.

\section{Acknowledgments}

This work was supported by FCT (Portugal) and FEDER, grant PTDCI/AGR-ALI/71262/2006, Vinnova (Chronic inflammation, KIDaT), EU's $6^{\text {th }}$ Framework Program (Eicosanox, LSMH-CT-2004-005003), Torsten and Ragnar Söderbergs Foundation, The Swedish research Council and Heart-Lung Foundation. Bruno Gago is a PDBEB student from Center for Neurosciences and Cell Biology (CNC) supported by fellowship SFRH/BD/15228/2004.

\section{Appendix A. Supplementary data}

Supplementary data associated with this article can be found, in the online version, at doi:10.1016/j.freeradbiomed.2008.04.027.

\section{References}

[1] Suschek, C. V.; Schewe, T.; Sies, H.; Kroncke, K. D. Nitrite, a naturally occurring precursor of nitric oxide that acts like a 'prodrug'. Biol. Chem. 387:499-506; 2006.

[2] Lundberg, J. O.; Weitzberg, E.; Cole, J. A.; Benjamin, N. Nitrate, bacteria and human health. Nat. Rev. Microbiol. 2:593-602; 2004

[3] Gladwin, M. T.; Schechter, A. N.; Kim-Shapiro, D. B.; Patel, R. P.; Hogg, N.; Shiva, S. Cannon 3rd, R. O.; Kelm, M.; Wink, D. A.; Espey, M. G.; Oldfield, E. H.; Pluta, R. M.; Freeman, B. A.; Lancaster J. R., Jr.; Feelisch, M.; Lundberg, J. O. The emerging biology of the nitrite anion. Nat. Chem. Biol. 1:308-314; 2005

[4] Bryan, N. S. Nitrite in nitric oxide biology: cause or consequence? A systems-based review. Free Radic. Biol. Med. 41:691-701; 2006.

[5] Lundberg, J. O.; Weitzberg, E.; Gladwin, M. T. The nitrate-nitrite-nitric oxide pathway in physiology and therapeutics. Nat. Rev. Drug Discov. 2008

[6] Weitzberg, E.; Lundberg, J. O. Nonenzymatic nitric oxide production in humans. Nitric Oxide 2:1-7; 1998.

[7] McKnight, G. M.; Smith, L. M.; Drummond, R. S; Duncan, C. W.; Golden, M. Benjamin, N. Chemical synthesis of nitric oxide in the stomach from dietary nitrate in humans. Gut 40:211-214; 1997.

[8] Lundberg, J. O.; Weitzberg, E.; Lundberg, J. M.; Alving, K. Intragastric nitric oxide production in humans: measurements in expelled air. Gut 35:1543-1546; 1994.

[9] Benjamin, N.; O'Driscoll, F.; Dougall, H.; Duncan, C.; Smith, L.; Golden, M.; McKenzie, H. Stomach NO synthesis. Nature 368:502; 1994.

[10] Lundberg, J. O.; Carlsson, S.; Engstrand, L.; Morcos, E.; Wiklund, N. P.; Weitzberg, E. Urinary nitrite: more than a marker of infection. Urology 50:189-191; 1997.

[11] Benjamin, N.; Pattullo, S.; Weller, R.; Smith, L.; Ormerod, A. Wound licking and nitric oxide. Lancet 349:1776; 1997.

[12] Weller, R.; Pattullo, S.; Smith, L.; Golden, M.; Ormerod, A.; Benjamin, N. Nitric oxide is generated on the skin surface by reduction of sweat nitrate. J. Invest. Dermatol. 107:327-331; 1996

[13] Duncan, C.; Dougall, H.; Johnston, P.; Green, S.; Brogan, R.; Leifert, C.; Smith, L.; Golden, M.; Benjamin, N. Chemical generation of nitric oxide in the mouth from the enterosalivary circulation of dietary nitrate. Nat. Med. 1:546-551; 1995.

[14] McColl, K. E. Cancer of the gastric cardia. Best Pract. Res. Clin. Gastroenterol. 20:687-696; 2006

[15] McColl, K. E. When saliva meets acid: chemical warfare at the oesophagogastric junction. Gut 54:1-3; 2005.

[16] Crew, K. D.; Neugut, A. I. Epidemiology of gastric cancer. World J. Gastroenterol. 12:354-362; 2006

[17] Clemons, N. J.; McColl, K. E.; Fitzgerald, R. C. Nitric oxide and acid induce doublestrand DNA breaks in Barrett's esophagus carcinogenesis via distinct mechanisms. Gastroenterology 133:1198-1209; 2007.

[18] Tannenbaum, S. R.; Correa, P. Nitrate and gastric cancer risks. Nature 317:675-676; 1985.

[19] Dykhuizen, R. S. Frazer, R. Duncan, C. Smith, C. C.: Golden, M. Benjamin, N.; Leifert, C. Antimicrobial effect of acidified nitrite on gut pathogens: importance of dietary nitrate in host defense. Antimicrob. Agents Chemother. 40:1422-1425; 1996.

[20] Bjorne, H. H.; Petersson, J.; Phillipson, M.; Weitzberg, E.; Holm, L.; Lundberg, J. O. Nitrite in saliva increases gastric mucosal blood flow and mucus thickness. J. Clin. Invest. 113:106-114; 2004.

[21] Pique, J. M.; Whittle, B. J.; Esplugues, J. V. The vasodilator role of endogenous nitric oxide in the rat gastric microcirculation. Eur. J. Pharmacol. 174:293-296; 1989.

[22] Jansson, E. A.; Petersson, J.; Reinders, C.; Sobko, T.; Bjorne, H.; Phillipson, M.; Weitzberg, E.; Holm, L.; Lundberg, J. O. Protection from nonsteroidal anti-inflammatory drug (NSAID)-induced gastric ulcers by dietary nitrate. Free Radic. Biol. Med. 42:510-518; 2007.

[23] Gago, B.; Lundberg, J. O.; Barbosa, R. M.; Laranjinha, J. Red wine-dependent reduction of nitrite to nitric oxide in the stomach. Free Radic. Biol. Med. 43:1233-1242; 2007.

[24] Allen, A. D. Studies in the Hydrolysis and Alcoholysis of Some Organic Nitrites. J. Chem. Soc.1968-1974; 1954

[25] Noyes, W. A. Organic Syntheses, Collective, Volume 2. 1943: 108.

[26] Grossi, L.; Strazzari, S. A new synthesis of alkyl nitrites: the reaction of alkyl alcohols with nitric oxide in organic solvents. J. Org. Chem. 64:8076-8079; 1999.

[27] Upchurch, G. R., Jr.; Welch, G. N.; Loscalzo, J. S-nitrosothiols: chemistry, biochemistry, and biological actions. Adv. Pharmacol. 34:343-349; 1995.

[28] MacDonald, J. C.; Jonsson, A. Ethyl nitrite. The in vivo synthesis of a mutagenic substance from tobacco smoke and ethanol. Acta Chem. Scand. B 35:485-487; 1981 
[29] Deng, X. S.; Bludeau, P.; Deitrich, R. A. Formation of ethyl nitrite in vivo after ethanol administration. Alcohol 34:217-223; 2004

[30] Garthwaite, J.; Southam, E.; Boulton, C. L.; Nielsen, E. B.; Schmidt, K.; Mayer, B. Potent and selective inhibition of nitric oxide-sensitive guanylyl cyclase by $1 \mathrm{H}-$ [1,2,4] oxadiazolo[4,3-a]quinoxalin-1-one. Mol. Pharmacol. 48:184-188; 1995.

[31] Das, R. C.; Koga, O.; Suzuki, S. Chemical Ionization Mass-Spectrometry of Alkyl Nitrates and Nitrites. Bull. Chem. Soc. Jpn. 52:65-68; 1979.

[32] Howard, A.; Chopra, M.; Thurnham, D.; Strain, J.; Fuhrman, B.; Aviram, M. Red wine consumption and inhibition of LDL oxidation: what are the important components? Med. Hypotheses 59:101-104; 2002.

[33] Lugasi, A.; Hovari, J. Antioxidant properties of commercial alcoholic and nonalcoholic beverages. Die Nahrung 47:79-86; 2003.

[34] Goldberg, D. M.; Hoffman, B.; Yang, J.; Soleas, G. J. Phenolic constituents, furans, and total antioxidant status of distilled spirits. J. Agric. Food Chem. 47:3978-3985; 1999.

[35] Yoshimura, T.; Sugata, H. Alcohol scavenges nitric oxide in gastric lumen. Nitric Oxide 6:347-352; 2002.

[36] Bunton, C. A.; Stedman, G. Mechanism of the azide-nitrite reaction .3. Reaction in [0-18] water. J. Chem. Soc.3466-3474; 1959.

[37] Nguyen, M. T.; Hegarty, A. F. Protonation of nitrous-acid and formation of the nitrosating agent $\mathrm{No}^{+}-$an abinitio study. J. Chem. Soc. [Perkin 2]2037-2041; 1984

[38] Nedospasov, A. A. Is $\mathrm{N} 2 \mathrm{O} 3$ the main nitrosating intermediate in aerated nitric oxide (NO) solutions in vivo? If so, where, when, and which one? J. Biochem. Mol. Toxicol. 16:109-120; 2002.

[39] Li, H.; Duncan, C.; Townend, J.; Killham, K.; Smith, L. M.; Johnston, P.; Dykhuizen, R.; Kelly, D.; Golden, M.; Benjamin, N.; Leifert, C. Nitrate-reducing bacteria on rat tongues. Appl. Environ. Microbiol. 63:924-930; 1997.

[40] Spiegelhalder, B.; Eisenbrand, G.; Preussmann, R. Influence of dietary nitrate on nitrite content of human saliva: possible relevance to in vivo formation of $\mathrm{N}$ nitroso compounds. Food Cosm. Toxicol. 14:545-548; 1976.

[41] Peri, L.; Pietraforte, D.; Scorza, G.; Napolitano, A.; Fogliano, V.; Minetti, M. Apples increase nitric oxide production by human saliva at the acidic $\mathrm{pH}$ of the stomach: a new biologica function for polyphenols with a catechol group? Free Radic. Biol. Med. 39:668-681; 2005

[42] Takahama, U.; Oniki, T.; Hirota, S. Oxidation of quercetin by salivary components. Quercetin-dependent reduction of salivary nitrite under acidic conditions producing nitric oxide. J. Agric. Food Chem. 50:4317-4322; 2002.

[43] Carlsson, S.; Wiklund, N. P.; Engstrand, L.; Weitzberg, E.; Lundberg, J. O. Effects of $\mathrm{pH}$, nitrite, and ascorbic acid on nonenzymatic nitric oxide generation and bacterial growth in urine. Nitric Oxide 5:580-586; 2001.

[44] Kielbasa, W. B.; Bauer, J. A.; Fung, H. L. Analysis of isobutyl nitrite inhalant in rat and human blood: application for pharmacokinetic investigations. J. Chromatogr. $B$ Biomed. Sci. Appl. 734:83-89; 1999.

[45] Artz, J. D. Thatcher, G. R. NO release from NO donors and nitrovasodilators: comparisons between oxyhemoglobin and potentiometric assays. Chem. Res. Toxicol. 11:1393-1397; 1998.
[46] Nicolescu, A. C.; Reynolds, J. N.; Barclay, L. R.; Thatcher, G. R. Organic nitrites and NO: inhibition of lipid peroxidation and radical reactions. Chem. Res. Toxicol. 17:185-196; 2004

[47] Modin, A.; Bjorne, H.; Herulf, M.; Alving, K.; Weitzberg, E.; Lundberg, J. O. Nitritederived nitric oxide: a possible mediator of 'acidic-metabolic' vasodilation. Acta Physiol. Scand. 171:9-16; 2001.

[48] Kelbaek, H.; Floistrup, S.; Gjorup, T.; Christensen, N. J.; Hartling, O. J.; Godtfredsen, J. Central and peripheral haemodynamic changes after alcohol ingestion. Alcohol alcohol. (Oxford, Oxfordshire) 23:211-216; 1988.

[49] Tawakol, A.; Omland, T.; Creager, M. A. Direct effect of ethanol on human vascular function. Am. J. Physiol. Heart Circ. Physiol. 286:H2468-H2473; 2004.

[50] Moya, M. P.; Gow, A. J.; Califf, R. M.; Goldberg, R. N.; Stamler, J. S. Inhaled ethyl nitrite gas for persistent pulmonary hypertension of the newborn. Lancet 360:141-143; 2002.

[51] Ali, N. A. Eubanks, W. S.; Stamler, J. S.; Gow, A. J. Lagoo-Deenadayalan, S. A. Villegas, L.; El-Moalem, H. E.; Reynolds, J. D. A method to attenuate pneumoperitoneum-induced reductions in splanchnic blood flow. Ann. Surg. 241:256-261; 2005.

[52] Baccarani, A.; Yasui, K.; Olbrich, K. C.; El-Sabbagh, A.; Kovach, S.; Follmar, K. E.; Erdmann, D.; Levin, L. S.; Stamler, J. S.; Klitzman, B.; Zenn, M. R. Efficacy of ethyl nitrite in reversing surgical vasospasm. J. Reconstr. Microsurg. 23:257-262; 2007.

[53] Gago, B.: Nystrõm, T; Cavaleiro, C.: Barbosa, R. M. Lundberg J. O.: Laranjinha, J. Nitrite and red wine interact in the stomach yielding nitric oxide which induces local smooth muscle relaxation (abstract). Free Radic. Res. 41:S29; 2007.

[54] Bor, S.; Bor-Caymaz, C.; Tobey, N. A.; Abdulnour-Nakhoul, S.; Orlando, R. C. Esophageal exposure to ethanol increases risk of acid damage in rabbit esophagus. Dig. Dis. Sci. 44:290-300; 1999.

[55] Tonnesen, H.; Andersen, J. R.; Christoffersen, P.; Kaas-Claesson, N. Reflux oesophagitis in heavy drinkers. Effect of ranitidine and alginate/metoclopramide. Digestion 38:69-73; 1987.

[56] Vitale, G. C.; Cheadle, W. G.; Patel, B.; Sadek, S. A.; Michel, M. E.; Cuschieri, A. The effect of alcohol on nocturnal gastroesophageal reflux. Jama 258:2077-2079; 1987.

[57] Rosito, G. A.; Fuchs, F. D.; Duncan, B. B. Dose-dependent biphasic effect of ethanol on 24-h blood pressure in normotensive subjects. Am. J. Hypertens 12:236-240; 1999.

[58] Kodavali, L.; Townsend, R. R. Alcohol and its relationship to blood pressure. Curr. Hypertens. Rep. 8:338-344; 2006.

[59] Kanner, J.; Lapidot, T. The stomach as a bioreactor: dietary lipid peroxidation in the gastric fluid and the effects of plant-derived antioxidants. Free Radic. Biol. Med. 31:1388-1395; 2001

[60] Cui, T.; Schopfer, F. J.; Zhang, J.; Chen, K.; Ichikawa, T.; Baker, P. R.; Batthyany, C.; Chacko, B. K.; Feng, X.; Patel, R. P.; Agarwal, A.; Freeman, B. A.; Chen, Y. E. Nitrated fatty acids: Endogenous anti-inflammatory signaling mediators. J. Biol. Chem. 281:35686-35698; 2006 